Article

\title{
Assessment of Snow Status Changes Using L-HH Temporal-Coherence Components at Mt. Dagu, China
}

\author{
Yong Wang ${ }^{1,2,3, *}$, Lei Wang ${ }^{1}$, Hong $\mathrm{Li}^{4}$, Yuanyuan Yang ${ }^{1}$ and Taoli Yang ${ }^{1}$
}

1 School of Resources and Environment, University of Electronic and Science Technology of China (UESTC), 2006 Xiyuan Avenue, West Hi-tech Zone, Chengdu 611731, China;

E-Mails: leimingalex@163.com (L.W.); yangyy.uestc@outlook.com (Y.Y.); yangtl@uestc.edu.cn (T.Y.)

2 Department of Geography, Planning, and Environment, East Carolina University, Greenville, NC 27858, USA

3 Institute of Remote Sensing Big Data, Big Data Research Center of UESTC, 2006 Xiyuan Avenue, West Hi-tech Zone, Chengdu 611731, China

4 Department of Management and Information Systems, East Carolina University, Greenville, NC 27858, USA; E-Mail: lih@ecu.edu

* Author to whom correspondence should be addressed; E-Mail: wangy2012@uestc.edu.cn or wangy@ecu.edu; Tel.: +1-252-328-1043; Fax: +1-252-328-6054.

Academic Editors: Richard Gloaguen and Prasad S. Thenkabail

Received: 30 March 2015 / Accepted: 2 September 2015 / Published: 11 September 2015

\begin{abstract}
Multitemporal Phased Array type L-band Synthetic Aperture Radar (PALSAR) horizontally transmitted and horizontally received $(\mathrm{HH})$ coherence data was decomposed into temporal-coherence, spatial-coherence, and thermal noise components. The multitemporal data spanned between February and May of 2008, and consisted of two pairs of interferometric SAR (InSAR) images formed by consecutive repeat passes. With the analysis of ancillary data, a snow increase process and a snow decrease process were determined. Then, the multiple temporal-coherence components were used to study the variation of thawing and freezing statuses of snow because the components can mostly reflect the temporal change of the snow that occurred between two data acquisitions. Compared with snow mapping results derived from optical images, the outcomes from the snow increase process and the snow decrease process reached an overall accuracy of $71.3 \%$ and $79.5 \%$, respectively. Being capable of delineating not only the areas with or without
\end{abstract}


snow cover but also status changes among no-snow, wet snow, and dry snow, we have developed a critical means to assess the water resource in alpine areas.

Keywords: change detection; interferometric SAR (InSAR); multitemporal coherence data; snow cover and status change; temporal-coherence component

\section{Introduction}

Annual and perennial snow and glacier in mountainous areas are important water resources. More than one-sixth of the Earth's population relies on the melting water from the snowpack and glaciers [1]. As humans face challenges of increasing populations, and environmental and climate changes it is increasingly important to understand and assess the area extent, volume, and spatiotemporal variation of snow and glaciers. Measuring them directly in high and remote mountains is impractical. Remote sensing techniques provide frequent observation over large spatial extents, and can evaluate the spatiotemporal changes. Optical remote sensing is successful in mapping snow and glaciers. However, cloud cover over mountains is an obstacle for continuous mapping.

Microwave energy of synthetic aperture radar (SAR) can penetrate cloud cover. Baghdadi, et al. [2] explore the possibility of mapping wet snow using multiple temporal SAR data. Nagler and Rott [3] use a pair of C-band vertically transmitted and vertically received (C-VV) images and a threshold of $-3.0 \mathrm{~dB}$ to delineate wet snow and dry snow areas. However, the ratio approach is not suitable for L-band horizontally transmitted and horizontally received (L-HH) or L-band VV (L-VV) data because the co-polarized backscatter values from both types of snow areas as well as from bare ground are similar. Instead, L-band polarimetric data are employed [4-6]. Values of the polarization fraction and other polarimetric features are effective for identifying the snow-covered area from the no-snow area, debris covered glacier, and vegetation [6]. Unfortunately, the mapping methods with the polarimetric data cannot be done routinely because the volume of existing polarimetric data is relatively small. Thus, an alternative is sought.

Since the status of snow on the alpine ground is mainly influenced by solar energy fluxes, the annual status can be dry or wet, or even be completely melted. Intuitively, the status change should result in coherence variation of an InSAR dataset. A relationship between the coherence value and thawing/freezing change exists [7-9]. For examples, C-band InSAR coherence data are used to estimate snow cover changes in Greenland [7,8] and Tibet Plateau [9-11]. The coherence data are able to distinguish the wet snow from dry snow as well as other land cover types [7-11]. However, the penetration depth into the snowpack from the microwave energy at C-band might be shallow. The radar backscatter comes mainly from the air-snow interface and the subsurface area immediately beneath the interface. The sensitivity to the surface variation or immediate subsurface change could hinder the applicability of C-band coherence data. Furthermore, the coherence degrades greatly when the baseline in either space or time is long. On the other hand, the coherence increases generally in snow-covered areas as the radar wavelength increases. In addition, the coherence in L-band degrades less than that in C-band at the same time or space baseline. Therefore, our objectives are (i) to assess the ability to use 
the repeat pass L-HH coherence data to detect changes of snow statuses, and (ii) to develop a method to map areas where changes happen.

\section{Study Area and Data}

\subsection{Study Area}

Mt. Dagu lies to the middle of the Hengduan Mountain Range. The Range is located at the southeastern edge of the Qinghai-Tibetan Plateau. The peak of Dagu is centered near $32^{\circ} 12^{\prime} 33.37^{\prime \prime} \mathrm{N}$ and $102^{\circ} 45^{\prime} 30.99^{\prime \prime} \mathrm{E}$ (Figure 1). Elevation values of the area range from 2436 to $5164 \mathrm{~m}$ above the mean sea level. The mean elevation value is $4045 \mathrm{~m}$. Locally, the terrain is rugged with high ridges and deep valleys. The difference in elevation values of the ridge and valley can easily exceed hundreds of meters. Snow falls mainly from late autumn, through winter, to early spring. Historically, Dagu was a huge flat ice cap during the Quaternary glaciation age dating back to about three million years ago. Nineteen modern alpine glaciers are currently identifiable. Within the study area, the average daily air temperature is near $-5.3{ }^{\circ} \mathrm{C}$ in January. In July, the average temperature is about $12.8^{\circ} \mathrm{C}$. With variation of the annual temperature from below $0{ }^{\circ} \mathrm{C}$ in winter to above zero degree in summer, annual snow fall/accumulation and melt processes cause intra- and inter- expansion and contraction of annual and perennial snow.

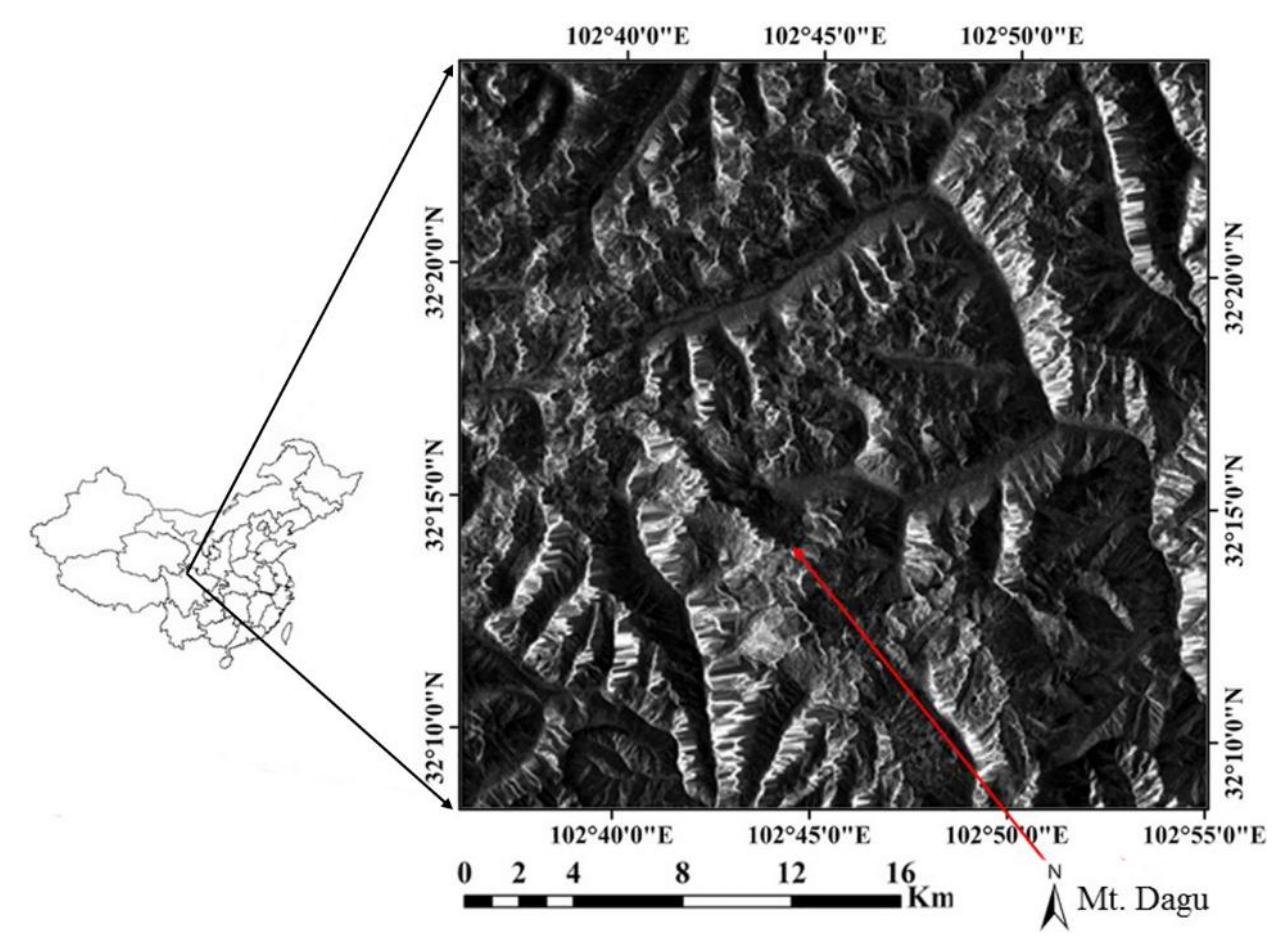

Figure 1. PALSAR L-HH image in ground range showing Mt. Dagu, Sichuan, China. The image is in gray scale, and covers an area of $27 \mathrm{~km} \times 27 \mathrm{~km}$.

\subsection{Data Sets and Data Selection}

Multitemporal PALSAR [12] data were obtained at the Alaska Satellite Facility [13]. The repeat cycle of PALSAR was 46 days. Due to the rugged terrain that causes foreshortening, overlay, and shadow, a similar incidence angle was considered in data selection. A short perpendicular baseline within an InSAR 
image pair was desired. The minimal amount of temporal de-correlation in observations was preferred. Together, three SAR images between 22 February 2008 and 24 May 2008 were chosen (Table 1). The incidence angle at the center of each image was 34.3 . All images were acquired around 3:40 p.m. Greenwich Mean Time or 11:40 p.m. locally. The perpendicular baseline varied from -191 to $419 \mathrm{~m}$. The images were from the fine beam single (FBS) mode comprising HH polarization only.

Table 1. Multitemporal of PALSAR InSAR HH data and land surface temperature (LST) derived from Moderate-resolution Imaging Spectroradiometer (MODIS) LST daily nighttime products.

\begin{tabular}{cccc}
\hline $\begin{array}{c}\text { Master-Slave Images } \\
\text { (Date Format: yyyymmdd) }\end{array}$ & $\begin{array}{c}\text { Perpendicular } \\
\text { Baseline (m) }\end{array}$ & $\begin{array}{c}\text { LST at Acquisition Time } \\
\text { of Master/Slave Data }\left({ }^{\circ} \mathbf{C}\right)\end{array}$ & Season \\
\hline $20080222-20080408$ & 419.13 & $-15 /-12$ & Winter-Spring \\
$20080408-20080524$ & -190.72 & $-12 / 2$ & Spring-Spring \\
\hline
\end{tabular}

The annual statuses of snow cover on the ground can change among each other, as shown in Figure 2a. Figure $2 b$ illustrates all possible changes of snow statues over one year. As the PALSAR has a repeat cycle of 46 days, locations or raster cells in the InSAR pair data can be covered by dry snow, wet snow, or no-snow. In particular, if the elevation value of a cell is above the tree line but below the snow line, the ground coverage should be dry snow and dry snow (Dry-Dry for short), dry snow and wet snow (Dry-Wet), dry snow and no-snow (Dry-No), wet snow and wet snow (Wet-Wet), wet snow and no-snow (Wet-No), no-snow and no-snow (No-No), no-snow and wet snow (No-Wet), no-snow and dry snow (No-Dry), or wet snow and dry snow (Wet-Dry) annually. If a cell is located above the snow line, the coverage should be Wet-Wet, Wet-Dry, Dry-Dry, or Dry-Wet. In the two-word pairs, the first word stands for the snow status when the master image is acquired and the second one the snow status when the slave image is collected.

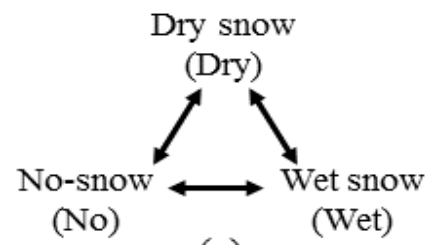

(a)

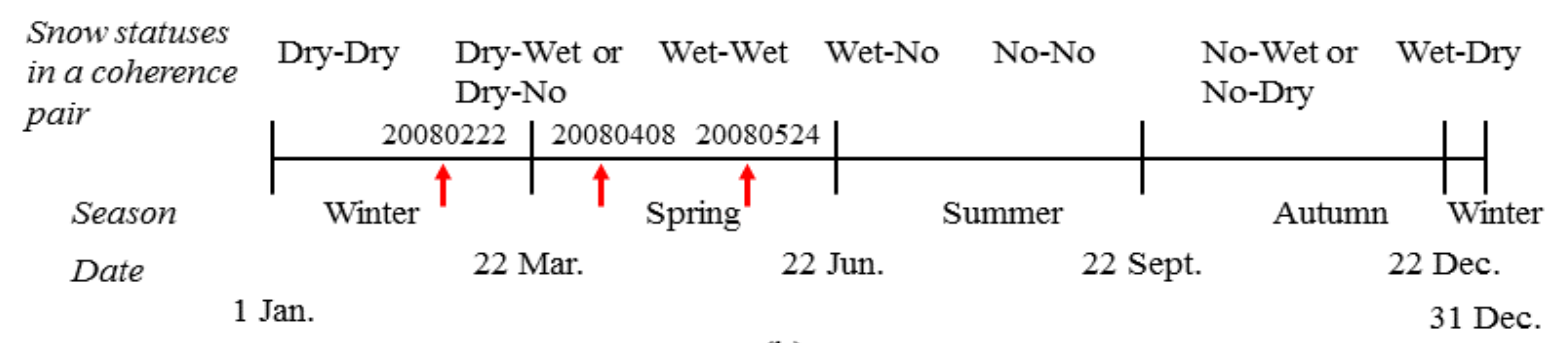

(b)

Figure 2. (a) Possible statuses and status changes of snow on the ground; (b) Nine statuses of snow within a pair of master and slave images from January to December. Red arrows showed acquisition dates of PALSAR data used in this study. 
Land surface temperature directly affects the freezing or thawing status of snow cover. In the determination of the snow status, the Moderate-resolution Imaging Spectroradiometer (MODIS) land surface temperature products were downloaded. Since PALSAR data were acquired at 11:40 p.m. locally, the daily nighttime average temperature was considered. The temperature related to PALSAR acquisition time is derived and listed in Table 1.

Advanced Spaceborne Thermal Emission and Reflection Radiometer (ASTER) Global DEM (GDEM)-version 2 was downloaded. The DEM data assisted the analysis in three aspects, the decomposition of the observed coherence into three sub-coherence components, the creation of the layover/shadow mask, and the computation of the local tree line and snow line.

Landsat 5 TM data of 130/38 (path/row) and 131/38 (path/row) from 18 September 2007 to 15 May 2008 were downloaded. As the study area was inaccessible, TM images were used to delineate permanent snow cover, grazing area or seasonal snow cover, and vegetated surface. TM images with the closest acquisition time to that of the PALSAR data were utilized to assess the proposed snow map method in which PALSAR coherence data are used.

The PALSAR FBS single look complex (SLC) data have the azimuth resolution of $3.2 \mathrm{~m}$ and the slant range resolution of $4.7 \mathrm{~m}$. To be compatible with the resolution $(30 \mathrm{~m}$ by $30 \mathrm{~m}$ ) of Landsat 5 and DEM data, the FBS data were multi-looked with 9 in the azimuth direction and 4 in the slant range direction, and then rasterized with a cell size of $30 \mathrm{~m} \times 30 \mathrm{~m}$ in the azimuth and ground range directions.

\section{Approach}

Overall, the approach includes the establishment of local tree and snow lines, delineation of multiple temporal-coherence components, determination of areas covered with and without snow in the snow accumulation period (February to April of 2008) and snowmelt period (April to May of 2008), and assessment of snow status changes between February and May.

\subsection{Establishment of Local Tree Line and Snow Line as a Priori Knowledge}

Although the typical elevation values for the tree line and snow line are $3048 \mathrm{~m}(10,000 \mathrm{ft}$.$) and$ $4267 \mathrm{~m}$ (14,000 ft.), respectively, the value for each line differs from location to location due to the interplay of altitude, latitude, and local environments. Thus, elevation values for local tree line and snow line as a priori knowledge are needed. In the study area, virgin forest is typically found under the elevation value of $3800 \mathrm{~m}$. Mountain rhododendron forest exists in the elevation value above $3800 \mathrm{~m}$. Alpine meadow and brushwood are mainly distributed from 4000 to $4500 \mathrm{~m}$. To determine the elevation value for the tree line or snow line accurately, we carry out two main steps.

Table 2. Landsat 5 TM data. TM images with the closest acquisition dates to those of PALSAR data are italicized.

\begin{tabular}{cccccc}
\hline $\begin{array}{c}\text { Acquisition Date } \\
\text { (yyyymmdd) }\end{array}$ & Path/Row & Season & $\begin{array}{c}\text { Acquisition Date } \\
\text { (yyyymmdd) }\end{array}$ & Path/Row & Season \\
\hline 20070918 & $130 / 038$ & Summer & 20080209 & $130 / 038$ & Winter \\
20080303 & $131 / 038$ & Winter & 20080328 & $130 / 038$ & Spring \\
20080404 & $131 / 038$ & Spring & 20080515 & $130 / 038$ & Spring \\
20081123 & $130 / 038$ & Fall & & & \\
\hline
\end{tabular}


Surface radiance products of Landsat 5 TM data (Table 2) are employed to derive snow areas and no-snow areas as binary images using an object-oriented glacier mapping method [14]. Seven binary images have been derived. Because TM data are acquired in four seasons of two years (Table 2), the intra- and inter- annual variation of areal extents of snow cover can be assessed. During the snow accumulation period, wet snow and dry snow typically extend the ground coverage. As temperature rises above $0{ }^{\circ} \mathrm{C}$ in the snowmelt period, dry snow melts and becomes wet snow. The wet snow can be completely melted if temperature is continuously above $0{ }^{\circ} \mathrm{C}$. Bare soil, derbies of rock, rocks, or sparse grassy vegetation can be revealed in grazing zone, and the no-snow area reaches its maximum in late summer or early fall.

To determine the vegetation, grazing area, and permanent snow area as three landuse and land cover (LULC) types, we first apply three logical operations to seven binary images of the snow and no-snow covers derived previously as

$$
\left\{\begin{array}{l}
S=S_{1} \cap S_{2} \cap \cdots \cap S_{7} \\
G=\left(S_{1} \cup S_{2} \cup \cdots \cup S_{7}\right) \cap \bar{S} \\
V=\overline{S \cup G}
\end{array}\right.
$$

In Equation (1), $S_{i}$ is area of the snow cover type on the $i$ th $(i=1,2, \ldots, 7)$ Landsat datasets in Table 2. $\cap, \cup$, and - are logical operators of "AND", "OR" and "NOT", respectively. Thus, $S$ is the intersection of the snow areas, and is the permanent snow cover. $G$, the grazing area is a union that is of the maximum and possible spatial extend of the grazing area. $V$ is the vegetated surface and is not $S$ or $G$. Then, a summary LULC map consisting of $S, G$ and $V$ is derived. After overlaying the summary LULC map on the GDEM data, and extracting the elevation values of cells in each LULC category, we obtain a histogram for each class. The histogram curves are used to determine the local tree line and snow line.

\subsection{Decomposition of Multitemporal Coherence Data}

The observed coherence, $\gamma_{\text {oberserved }}$ of an InSAR image of repeat-pass SAR datasets can be partitioned into three sub-components as [15]

$$
\gamma_{\text {observed }}=\frac{\sum\left\langle\mu_{1} \mu_{2}^{*}\right\rangle}{\sqrt{\sum\left\langle\mu_{1} \mu_{1}^{*}\right\rangle \sum\left\langle\mu_{2} \mu_{2}^{*}\right\rangle}}=\gamma_{\text {temporal }} \gamma_{\text {spatial }} \gamma_{\text {noise }}
$$

or

$$
\gamma_{\text {temporal }}=\frac{\gamma_{\text {observed }}}{\gamma_{\text {spatial }} \gamma_{\text {noise }}}
$$

$\mu_{1}$ and $\mu_{2}$ are two co-registered complex images. * is the conjugate operator of a complex number. $\gamma_{\text {temporal }}$ is the temporal-coherence component. $\gamma_{\text {spatial }}$ is the spatial coherence component depending on the viewing geometry of the two acquisitions. $\gamma_{n o i s e}$ is the thermal noise component.

With the decomposition method and for distributed targets, $\gamma_{\text {spatial }}$ can be estimated as $[15,16]$

$$
\gamma_{\text {spatial }}=\frac{B_{a}-\left|\Delta f_{a}\right|}{B_{a}} \frac{B_{r}-\left|\Delta f_{r}\right|}{B_{r}}
$$


where $B_{a}$ is the bandwidth in the azimuth direction, and $B_{r}$ is the bandwidth in the slant range direction. For PALSAR, $\Delta f_{\mathrm{a}}$ is relatively small compared with bandwidth, and can be ignored. In the range direction, $\Delta f_{\mathrm{r}}$ can be computed from the wavenumber shift as

$$
\Delta f_{r}=-\frac{c}{\lambda} \frac{B_{p}}{r \tan (\theta-\alpha)}
$$

where $c$ is the speed of light. $\lambda$ is the radar wavelength. $B_{p}$ is the perpendicular baseline. $\gamma$ is the sensor-target distance. $\theta$ is the incidence angle. $\alpha$ is the slope that can be computed from a DEM.

$\gamma_{\text {noise }}$ can be equivalently computed as $[17,18]$

$$
\gamma_{\text {noise }}=\frac{1}{\sqrt{1+S N R_{1}^{-1}}} \frac{1}{\sqrt{1+S N R_{2}^{-1}}}
$$

where $S N R$ is the signal-to-noise ratio. $S N R$ is a function of the peak power of transmitter, pulse width, pulse repeat frequency, range resolution, temperature of receiver, and velocity of platform. The calculation of $S N R$ is generally complicated. Some parameters mentioned previously are typically approximated. The $S N R$ value available in the metadata file of PALSAR is high enough such that $\gamma_{\text {noise }}$ is close to 1 or a constant. Thus, the de-correlation caused by the thermal noise is negligible.

\subsection{Snow Mapping Using $\gamma_{\text {temporal }}$ Data}

Snow exists in the grazing and permanent snow areas, as well as in the area of low elevation values. The 46 days in time difference for a repeat-pass coherence pair would be too coarse in the assessment of the snow and its status change in the low elevation area because the snow on the ground may not last for an extended period of time. Thus, we ignore the snow and snow changes below the local tree line or areas with elevation values below the tree line are excluded. Because of the rugged terrain, and the side-looking image geometry, layover and shadow areas exist. Both can adversely affect the coherence analysis. With the available GDEM and PALSAR ephemeris, the layover and shadow areas are derived to form a layover/shadow mask. Then, the mask is used to exclude the layover and shadow areas.

In the snow accumulation period, an area without snow cover in a master scene can be covered by wet or dry snow in a slave scene. A wet snow area on a master image acquired in late fall or early winter becomes a dry snow area on the slave image acquired 46 days later. Due to the status changes of snow on the ground, $\gamma_{\text {temporal }}$ of a coherence pair should be low. In addition, the snow can be dry when both master and slave images are acquired. Even if the snow is dry when both master and slave images are acquired, it does not mean there is no change of snow during the 46-day time interval of two consecutive passes. Snow/ice particles can move caused by wind or even avalanche [19]. Snow depth and grain size can vary due to the addition of new snow or the erosion by wind [8]. Thus, temporal decorrelation occurs in dry snow or a coherence value is low $[8,19,20]$. The temperature was below $0{ }^{\circ} \mathrm{C}$ (Table 1 ) when 20080222 and 20080408 data were acquired. The snow was dry. The change of snow status of the 20080222-20080408 pair should include No-Dry, Dry-Dry and Dry-No. Therefore, as shown in Table 3, a low $\gamma_{\text {temporal }}$ value of the 20080222-20080408 pair should reveal areas with changes of snow cover statues. A high $\gamma_{\text {temporal }}$ value should delineate areas without snow change (i.e., No-No). The delineation 
of the change and no-change was outline in the first period of Figure 3. (The determination of a threshold value, $T_{\text {coherence }}$ is given in Section 4.3.1).

Table 3. $\gamma_{\text {temporal }}$ and changes of snow statuses. $T_{\text {coherence }}$ is the threshold to delineate the areas with or without snow changes.

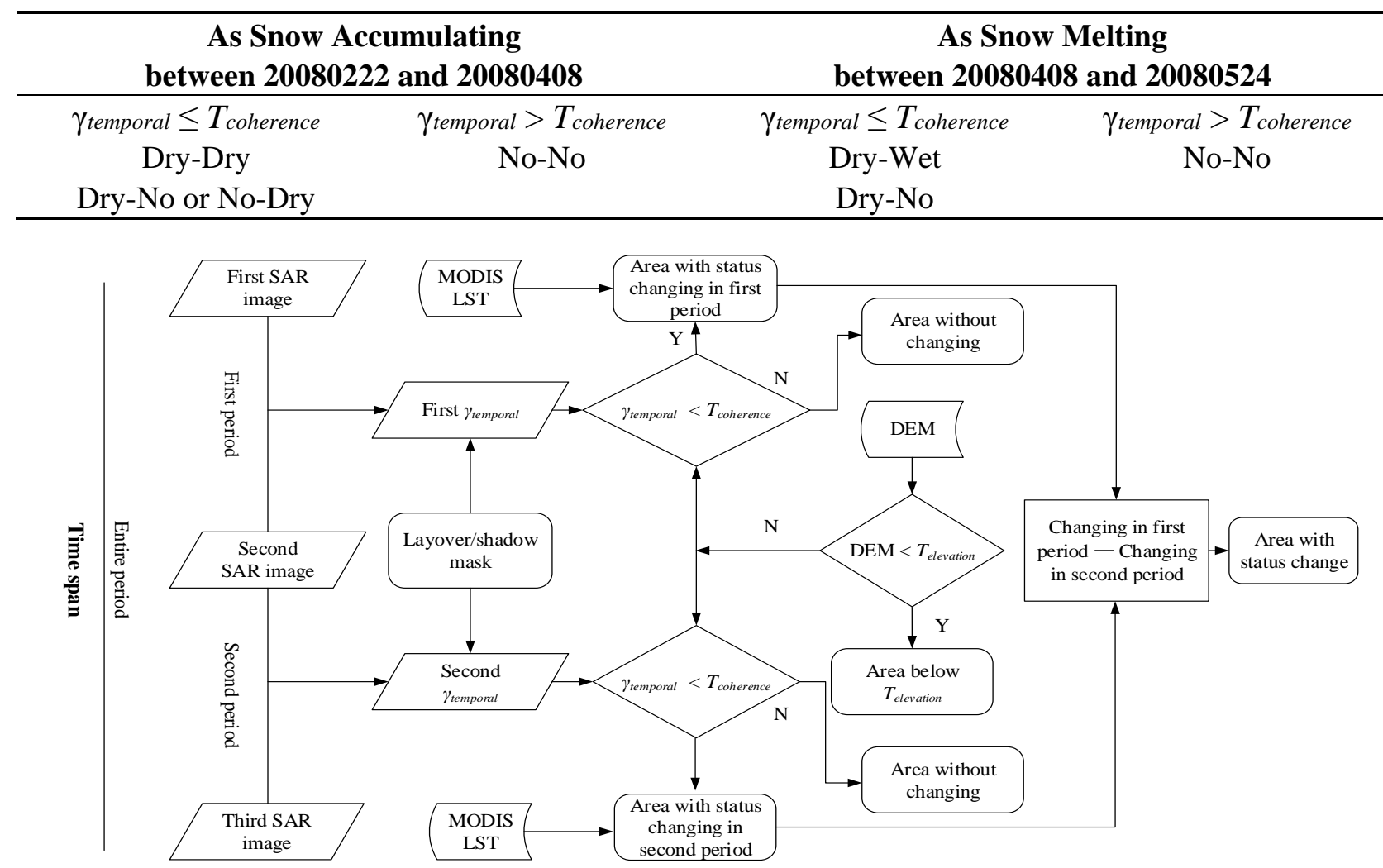

Figure 3. The algorithm to map area with or without snow change using $\gamma_{\text {temporal }}$ for locations above tree line in the first, second, and entire periods.

In the snowmelt period, the area coverage and snowpack depth decrease. The snow status changes include Dry-Wet, Dry-No, Wet-Wet, and Wet-No. The melting causes variations in the geometric shapes of snow and ice particles. Thus, as the wet snow image is paired with another image of other snow statuses, the coherence value of the pair is low [20]. Since the nighttime temperature was above $0{ }^{\circ} \mathrm{C}$ when the slave image of the 20080408-20080524 pair was acquired (Table 1), the pair should be in the snowmelt period. $\gamma_{\text {temporal }}$ of this pair should reflect the snow change or no-change (Table 3). In other words, a low $\gamma_{\text {temporal }}$ value indicated snow status of Dry-Wet or Dry-No, but a high $\gamma_{\text {temporal }}$ snow status of No-No.

Areas of no-snow status change, snow status change from dry snow to wet snow, and complete snowmelt from 2 February 2008 to 24 May 2008 can be derived by a subtraction operation of areas with and without snow statues changes in the accumulation and snowmelt periods (Figure 3).

\section{Result}

\subsection{Delineation of Local Tree and Snow Lines}

After the summary LULC layer was derived, and with the exclusion of the layover/shadow areas $\left(81.2 \mathrm{~km}^{2}\right)$, areas of the vegetated area, grazing zone, and permanent snow cover of the summary layer 
were $115.8 \mathrm{~km}^{2}, 514.5 \mathrm{~km}^{2}$, and $17.5 \mathrm{~km}^{2}$, respectively. After overlaying the summary map over the GDEM, the elevation values of vegetated area ranged from 2432 to $4480 \mathrm{~m}$. Within the grazing zone, the elevation values were between 3800 and $4821 \mathrm{~m}$. The range of elevation values for the permanent snow cover area was from 4480 to $5164 \mathrm{~m}$. The elevation threshold for the tree line at $3800 \mathrm{~m}$ was selected because the selection would maximize the areal coverage of the annual and perennial snow. Thus, the coverage above the tree line was the sum of the grazing zone and permanent snow covered area, which is $532.0 \mathrm{~km}^{2}$. The snow line could be $4600 \mathrm{~m}$.

\subsection{Decomposition of Multitemporal Coherence Data}

In mountainous areas, the topographic phase strongly affected the coherence estimation. The correction for the phase term was needed. The ASTER-GDEM was used to estimate the phase. The size of a coherence estimation window $(\mathrm{CEW})$ was determined after testing window sizes $3 \times 3,5 \times 5,7 \times 7$, and $9 \times 9$. The coherence value bias became stable when the size of window was greater than $5 \times 5$. In tradeoff between the spatial resolution and stability of the CEW, a window size of $5 \times 5$ was chosen. Then, $\gamma_{\text {observed }}$ of 20080222-20080408 pair and 20080408-20080524 pair were derived. Next, $\gamma_{\text {observed }}$ was decomposed into three subcomponents including $\gamma_{\text {temporal. }}$. As an example, $\gamma_{\text {observed }}$ and $\gamma_{\text {temporal }}$ of the 20080222-20080408 pair are shown in Figure 4. Visually, areas of violet decreased but areas with blue, cyan, and green increased (Figure $4 \mathrm{~b}$ cf. Figure $4 \mathrm{a}$ ). The changes in colors indicated the increase of coherence values. (Masked out areas are shown in black.) Histograms of both images were given in Figure 4c. The increase of coherence values was clear because of the rightwards shift of the histogram curve of $\gamma_{\text {temporal }}$ as compared to that of $\gamma_{\text {observed. }}$. Mean and median values of Figure $4 \mathrm{~b}$ were 0.21 and 0.18 , whereas mean and median values of Figure $4 \mathrm{a}$ were 0.19 and 0.14 , respectively.
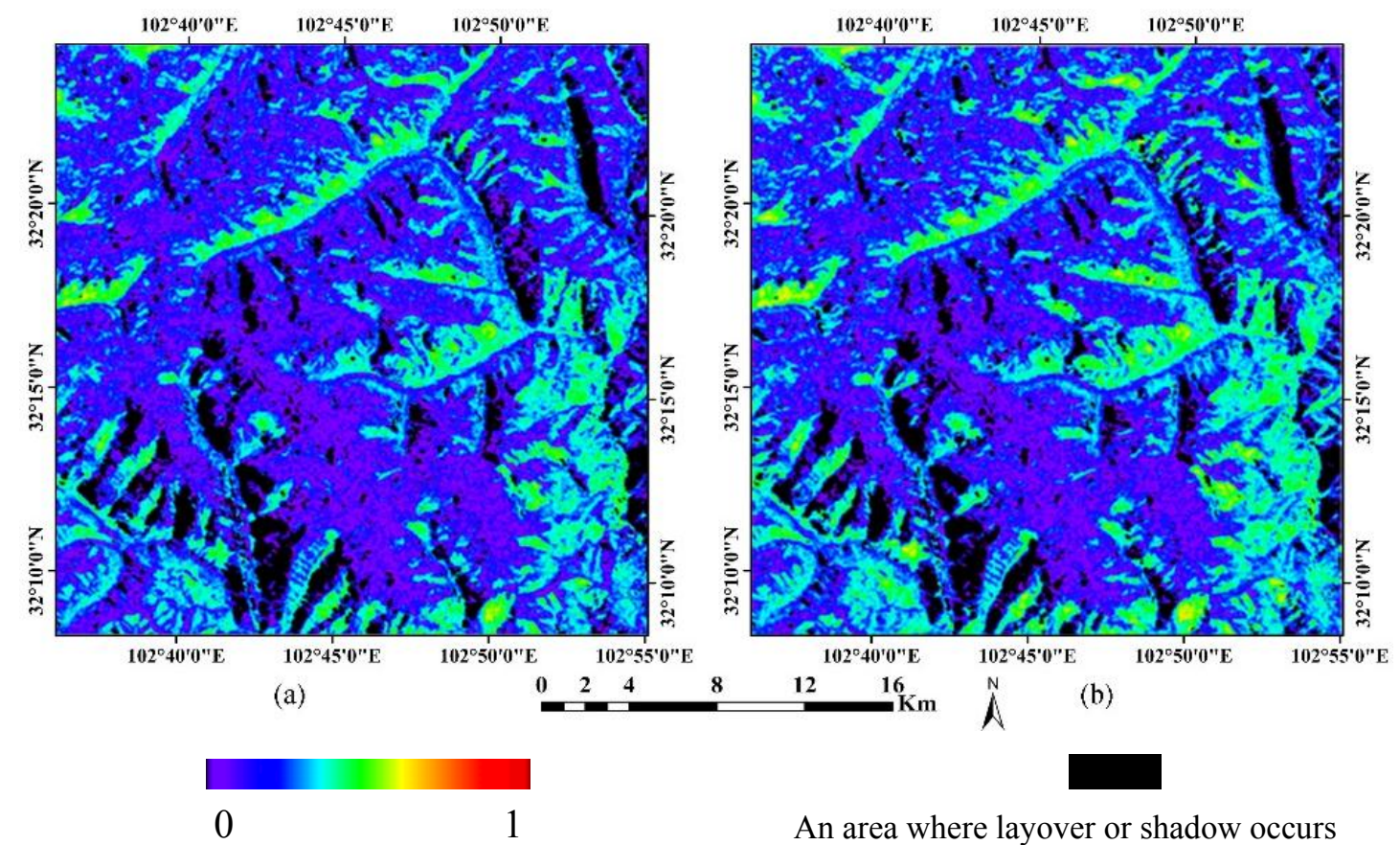

An area where layover or shadow occurs

Figure 4. Cont. 


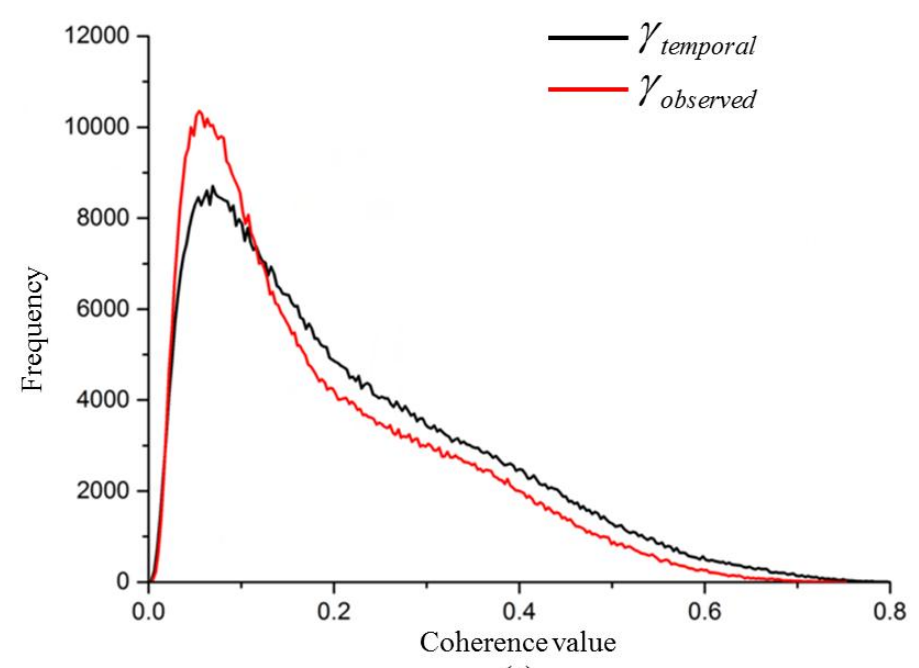

(c)

Figure 4. (a) The observed coherence data, robserved of 20080222-20080408 pair; (b) the temporal-coherence component, $\gamma_{\text {temporal }}$ of the pair; and (c) histograms of (a) and (b).

\subsection{Mapping Changes of Snow Areas in 2008}

\subsubsection{Determination of the Threshold Value, $T_{\text {coherence }}$}

To determine the threshold of coherence value, we analyzed the multi-temporal coherence images coupled with Landsat and ancillary datasets with following procedures. First, we selected numerous sample areas with each area of $255 \times 255$ pixels. The mean and median values of the coherence values from the pixels per sample area were derived. The layover and shadow areas, and the areas below $3800 \mathrm{~m}$ in elevation value within each sample area were masked out in the calculation. The average or median coherence value for areas above the tree line was low. This was especially true for the snow-covered area. Thus, significant change occurred between the two data acquisitions. Second, the subimage related to each sample area was extracted from TM data on 9 February 2008, 4 April 2008, and 15 May 2008. Within each subimage, areas with and without snow cover were mapped by the normalized difference snow index (NDSI) derived from TM data. A pair of snow cover maps was used to assess changes within the subimage area. Four possible changes are snow (at time 1) to snow (at time 2), snow to no-snow, no-snow to snow, and no-snow to no-snow.

With the assumption that the snow changes derived from TM data was true, the change map was overlaid to the temporal-coherence component image. We then linked cells of $\gamma_{\text {temporal }}$ image to the possible changes identified by snow maps derived from TM data. As an example, $\gamma_{\text {temporal }}$ from one sample extracted from 20080408-20080524 pair is shown in Figure 5a. The image was dominated by violet and blue colors, which indicates low $\gamma_{\text {temporal }}$. The mean value was 0.17 , and the median value 0.15. The true color composites of TM data acquired on 4 April 2008 (closest to the master SAR image), and 15 May 2008 (closest to the salve SAR image) covering the same area are shown in Figure 5b,c, respectively. Bright areas should be interpreted as snow-covered areas. There was a clear reduction in snow cover as time changed from April to May (Figure 5c cf. Figure 5b). Figure 5d showed the changes. Areas in white were covered with snow in both April and May. Areas in blue indicated that the snow was completely melted from April to May. Areas in red were no-snow in April and May. After 
overlaying Figure 5d onto Figure 5a, we extracted cells belonging to each change category. Histograms of the categories were obtained (Figure 5e). Three curves intercepted near 0.16. The interception around 0.16 was observed in numerous cases. Therefore, $T_{\text {coherence }}=0.16$ was determined.

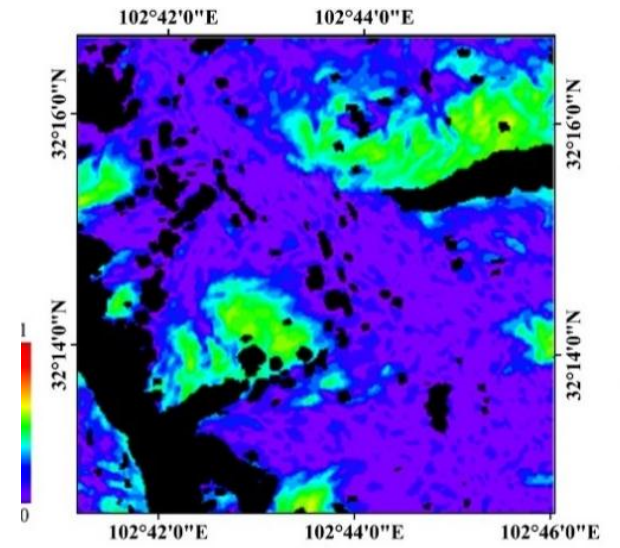

(a)

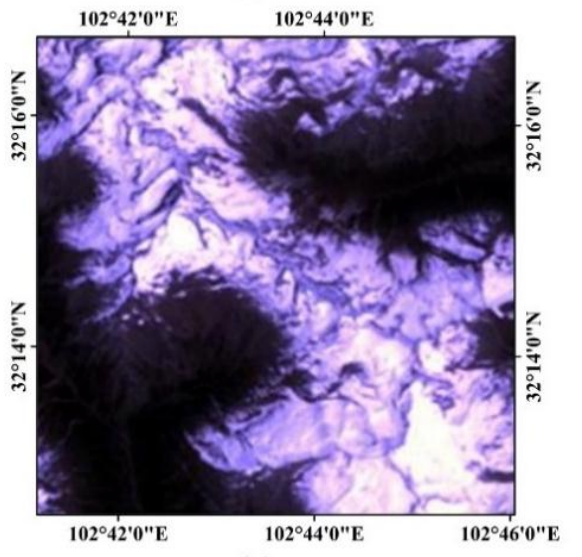

(c)

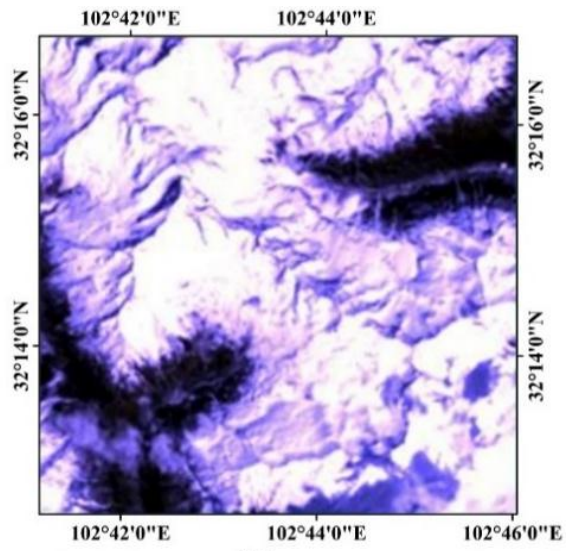

(b)

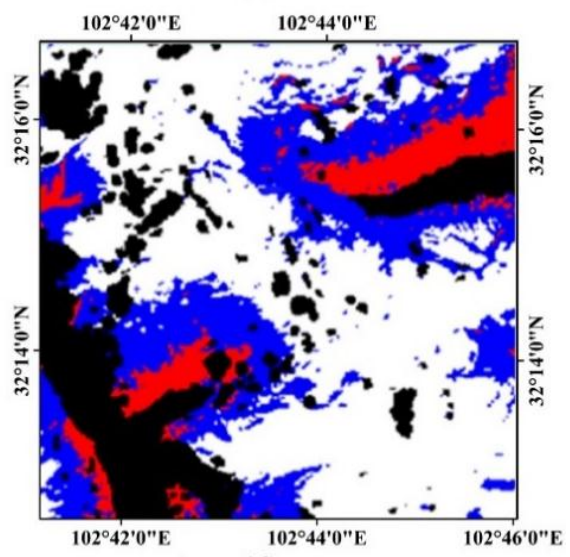

(d)

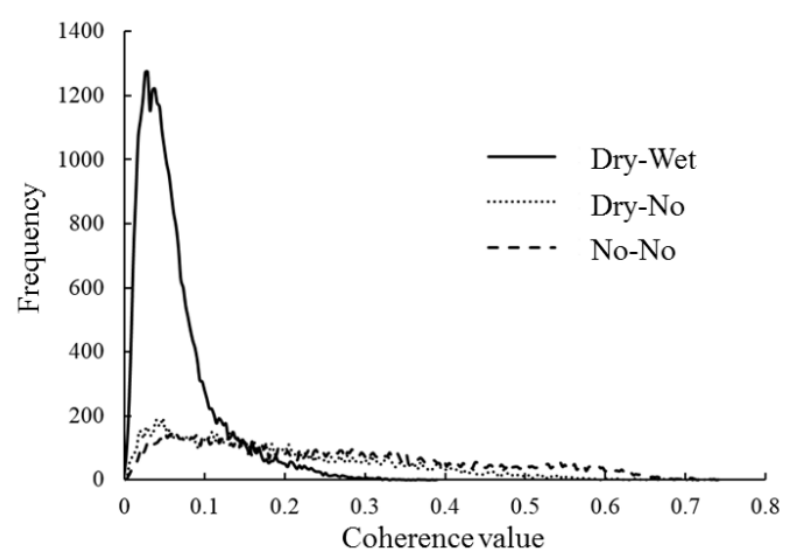

(e)

Figure 5. (a) Temporal-coherence component of a sample area extracted from 20080408-20080524 pair. (b) A true color composite of Landsat 5 TM data acquired on 4 April 2008. (c) A true color composite of TM data acquired on 5 May 2008. (d) Snow changes that occurred between 4 April and 15 May of 2008. Areas in white were snow-covered area. Areas in blue indicated that the snow was completely melted from April to May. Areas in red were no-snow on both dates. (e) The histogram of (a) categorized by each type of snow changes was derived from (d). The marked out areas were in black in (a) and (d). 


\subsubsection{Mapping Snow Area Change in Snow Accumulation Period (from February to April)}

Since 20080222-20080408 pair was acquired in late winter and early spring seasons, snow in the area should accumulate. Because of low average value of $\gamma_{\text {temporal }}$, the snow would change greatly (Figure $4 b$ ). Using the algorithm outlined for the first period (Figure 3), we mapped individual cells belonging to the area with snow increase in blue, area without snow change in green, or area below tree line in red (Figure 6). The total area with an increase of snow was $348.9 \mathrm{~km}^{2}$, and the area without snow change was $183.1 \mathrm{~km}^{2}$ (Table 4). According the LST data (Table 1), the snow status was Dry-Dry (Table 3).

Table 4. Areas $\left(\mathrm{km}^{2}\right)$ with snow increase or decrease between Feburary and May of 2008.

\begin{tabular}{lccc}
\hline & Area with Snow Increase & Area without Change & Area with Snow Decrease \\
\hline $20080222-20080408$ pair & 348.9 & 183.1 & 224.1 \\
\hline
\end{tabular}

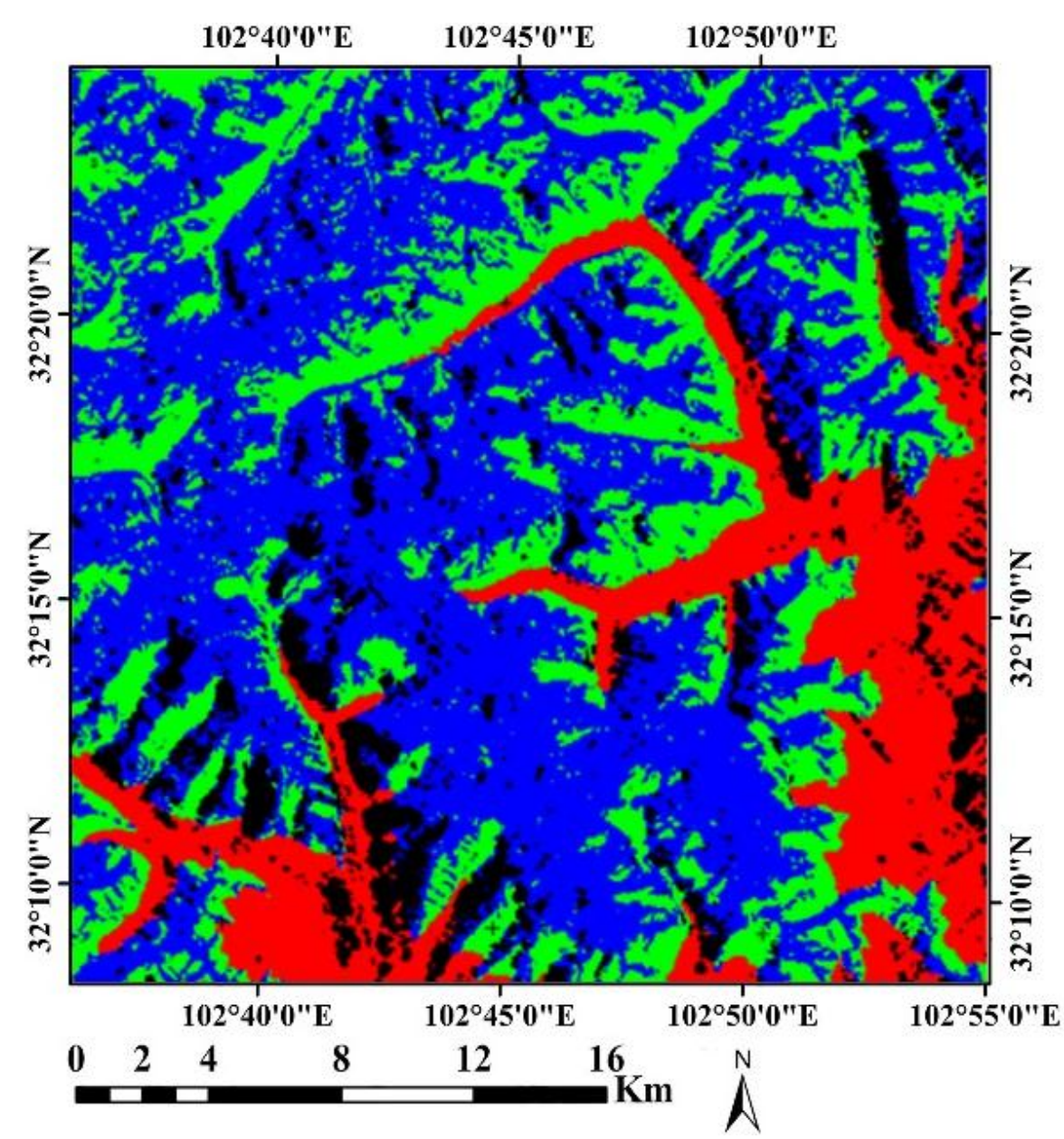

Figure 6. Snow map derived from $\gamma_{\text {temporal }}$ of 20080222-20080408. Areas with snow increase, without snow change, and below tree line were colored in blue, green, and red, respectively.

\subsubsection{Mapping Snow Area Change in Snowmelt Period (from April to May)}

For 20080408-20080524 pair, the LST was $-12{ }^{\circ} \mathrm{C}$ at the acquisition time for the master image, but $2{ }^{\circ} \mathrm{C}$ when the slave image was acquired. The snow was in the snowmelt period. Therefore, the snow 
status should be Dry-Wet in the permanent snow covered area, and Dry-Wet or Dry-No in the grazing zone. With the algorithm outlined for the second period (Figure 3), we showed cells with snow decrease in blue color, and cells with no change of snow status in green color (Figure 7). The area showing the decrease of snow was $224.1 \mathrm{~km}^{2}$, but the area with no change of snow was $307.9 \mathrm{~km}^{2}$ (Table 4).

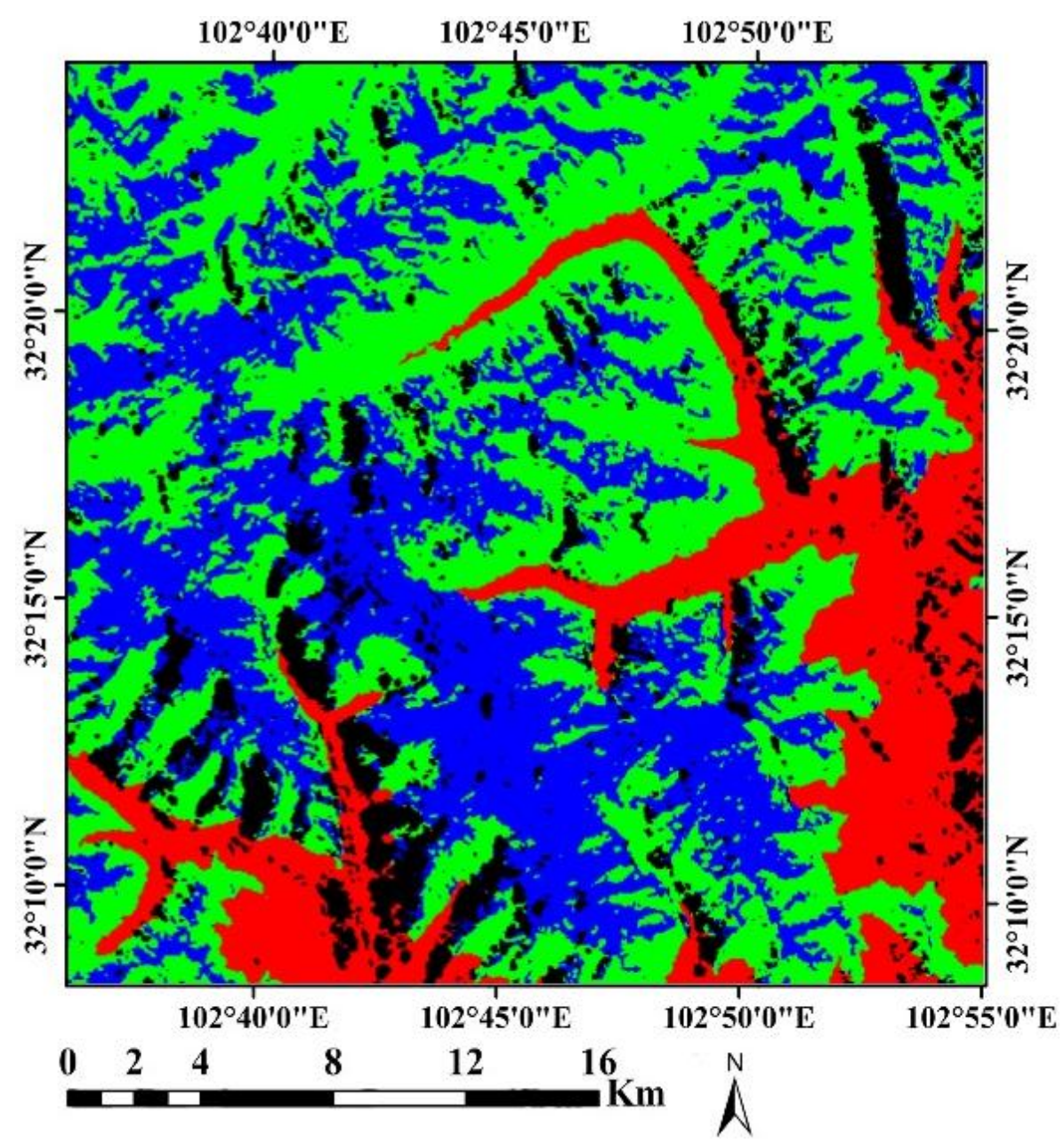

Figure 7. Snow map derived from $\gamma_{\text {temporal }}$ of 20080408-20080524. Areas with snow decrease, without snow change, and below tree line are blue, green, and red, respectively.

\subsubsection{Mapping Snow Area Change from February to May}

From 22 February to 8 April, the area with snow accumulation and Dry-Dry status was $348.9 \mathrm{~km}^{2}$. Between 8 April and 24 May, the area with decreased snow and Dry-Wet was $224.1 \mathrm{~km}^{2}$ (Table 4). Thus, there should be $124.8 \mathrm{~km}^{2}$ of area where the snow was melted completed from February to May. Subtracting the Dry-Wet area (the blue color in Figure 7) from the Dry-Dry area (the blue color in Figure 6), we identified the Dry-No area and showed the area in blue (Figure 8). In addition, the area without change was colored in green, and the area of snow melting (Dry-Wet) was colored yellow (Figure 8). Therefore, using three observations consecutively, we have achieved the objectives to assess the ability of using the repeat-pass PALSAR HH coherence data to detect the snow status change, and to develop an algorithm to map areas where the change occurs. 


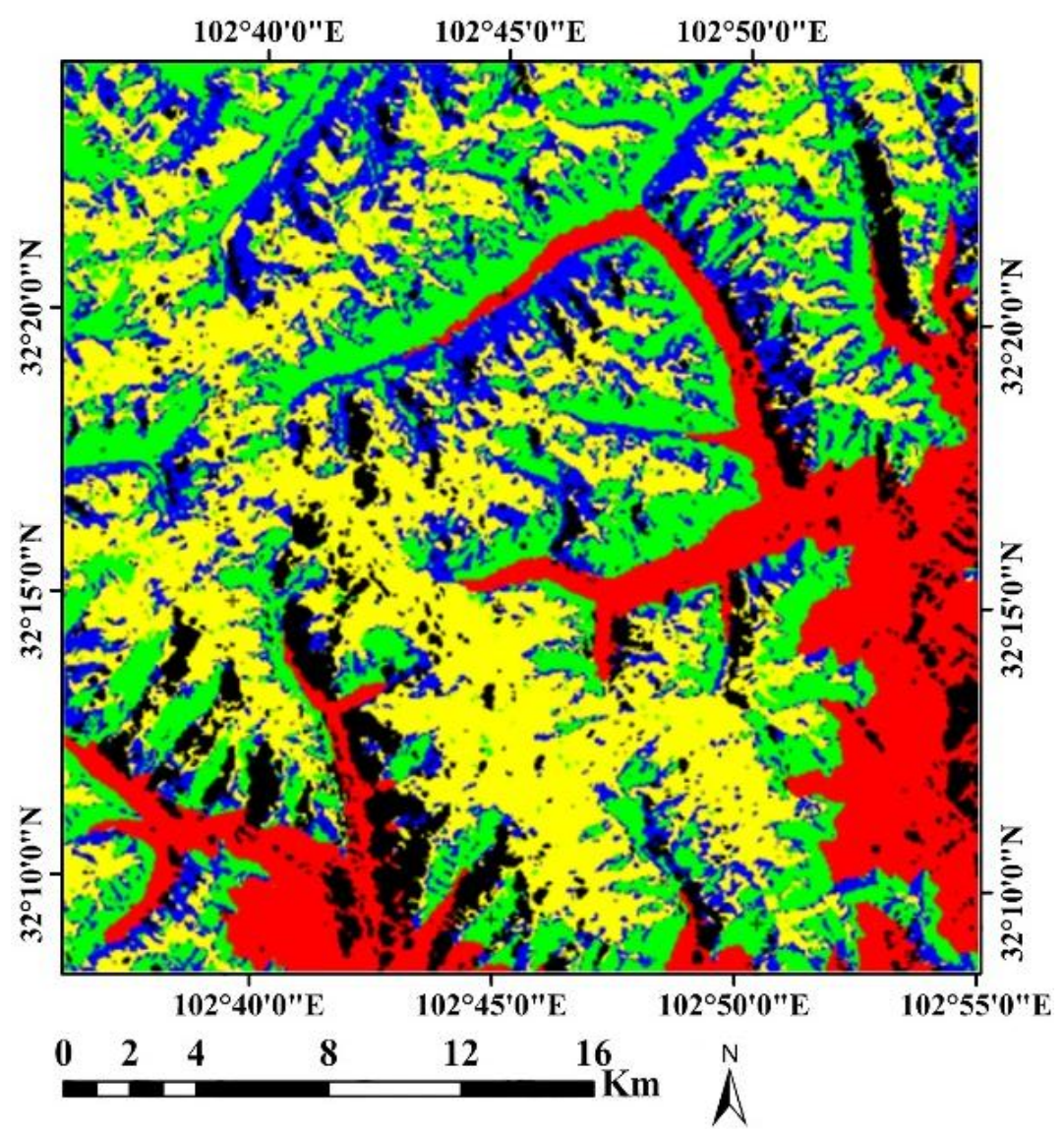

Figure 8. Snow status and status change between 22 February 2008 and 24 May 2008. Areas where snow melted completely or the snow status was Dry-No are blue. Areas of no change (Dry-Dry or No-No) are green. Areas of snow melting (Dry-Wet) are yellow. Areas below the tree line are red.

\section{Discussion}

\subsection{Comparison of Snow Maps Using $\gamma_{\text {temporal }}$ and Landsat 5 TM Data}

The snow areas derived cannot be directly assessed using in situ data. Alternatively, we identify three Landsat 5 TM images acquired closest to the acquisition dates of the PALSAR data, and derive the snow areas using NDSI. NDSI $\geq 0.4$ is widely used to determine the snow cover condition if there is no cloud over the snow area [21]. Generally, the higher the NDSI value is, the more the snow on the ground is. Thus, for a cell, if the first NDSI value is less than the second NDSI value, snow increased during this period. If the first NDSI value is greater than the second NDSI value, then snow decreased. The algorithm to map snow area changes is summarized in Figure 9.

Landsat 5 TM images having the closest acquisition time related to the coherence 20080222-20080408 dataset were on 9 February 2008 (the master image) and on 4 April 2008 (the slave image). Using the algorithm outlined, we derived areas of snow increase or no changes (Figure 10a). The increase in area was $399.0 \mathrm{~km}^{2}$, and the area without snow change was $133.0 \mathrm{~km}^{2}$. In comparison to Figure 6 and Figure 10a spatially, areas of increased snow identified by both maps were $297.6 \mathrm{~km}^{2}$. Areas of no snow change on the maps were $81.7 \mathrm{~km}^{2}$. Areas of the other two mismatching cases are also 
given in Table 5. The overall agreement defined as the sum of numbers in the major diagonal axis divided to the total number was $71.3 \%$. The agreement would be acceptable.

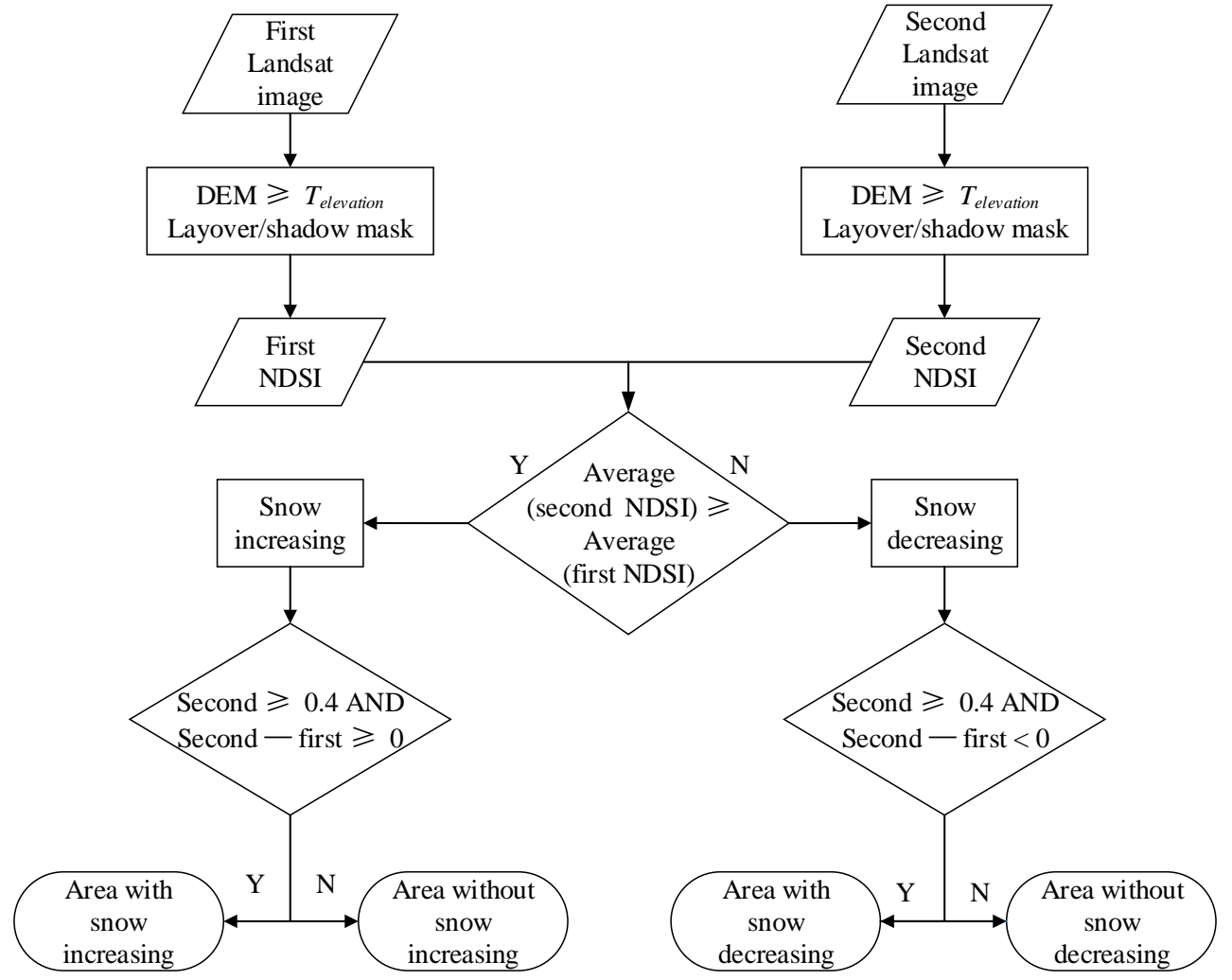

Figure 9. Areas with the snow increase in an accumulation period or the snow decrease in a snowmelt period.

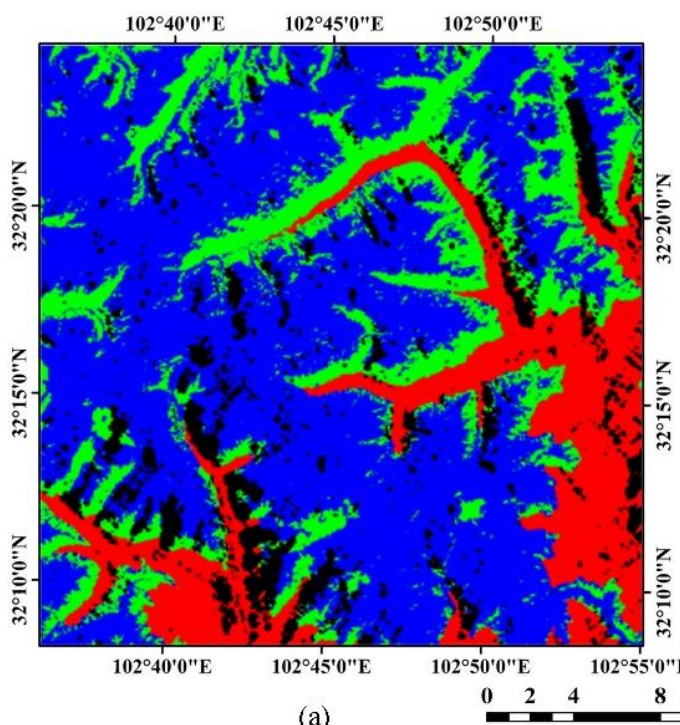

(a)

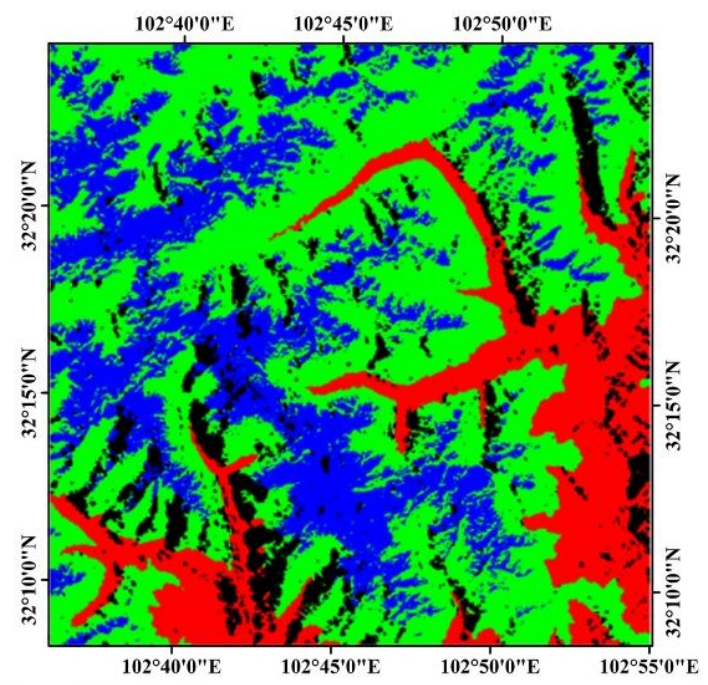

(b)

Figure 10. Snow maps using Landsat 5 image pairs. (a) The 9 February 2008 and 4 April 2008 pair. Areas in blue represent locations with snow increase. Areas without snow change are green. (b) The 4 April 2008 and 15 May 2008 pair. Areas with snow decrease are blue. Areas without change are green. In both (a) and (b), areas below tree line are red. The layover and shadow areas are black. 
Table 5. Spatial comparison of snow maps derived from coherence 20080222-20080408 pair and 20080209-20080404 Landsat 5 TM pair. Unit: km².

\begin{tabular}{|c|c|c|c|}
\hline$\gamma_{\text {temporal }}$ & Area with Snow Increase & Area without Change & Total \\
\hline Area with snow increase & 297.6 & 101.4 & 399.0 \\
\hline Area without snow change & 51.3 & 81.7 & 133.0 \\
\hline Total & 348.9 & 183.1 & \\
\hline
\end{tabular}

Similarly, for the coherence 20080408-20080524 pair, Landsat 5 TM images that are of the closest acquisition time were on 4 April 2008 (the master image) and on 15 May 2008 (the slave image). The area with snow decrease and the area without snow change were obtained (Figure 10b). The decrease in area was $175.2 \mathrm{~km}^{2}$. The area without snow change was $356.8 \mathrm{~km}^{2}$. The total area with snow decrease in both Figure 7 and Figure $10 \mathrm{~b}$ was $145.0 \mathrm{~km}^{2}$. The area with no change in snow was $277.7 \mathrm{~km}^{2}$. Areas of two mismatching cases are given in Table 6 . The overall agreement was $79.5 \%$, which should be satisfactory.

Table 6. Spatial comparison of snow maps derived from coherence 20080408-20080524 pair and 20080404-20080515 Landsat 5 TM pair. Unit: km².

\begin{tabular}{|c|c|c|c|}
\hline Landsat Data & $\begin{array}{c}\text { Area with Snow } \\
\text { Decrease }\end{array}$ & Area without Change & Total \\
\hline Area with snow decrease & 145.0 & 30.2 & 175.2 \\
\hline Area without snow change & 79.1 & 277.7 & 356.8 \\
\hline Total & 224.1 & 307.9 & \\
\hline
\end{tabular}

\subsection{Influence of Different $T_{\text {coherence Values on Mapping Results }}$}

$T_{\text {coherence }}=0.16$ is empirically determined. Different $T_{\text {coherence }}$ values should influence the results. Mapping outcomes using $T_{\text {coherence }}$ of 0.14 and 0.18 are derived, respectively. In the snow accumulation period and with the increase of $T_{\text {coherence }}$ from 0.14 to 0.18 , the spatial agreement increases from $61.9 \%$ to $74.4 \%$ (Table 7) as compared to the snow map derived from Landsat TM data (Figure 10a). The spatial agreement decreases from $80.1 \%$ to $77.8 \%$ in the snowmelt period (Table 7). Consequently, the percentages of spatial agreements vary but the variation should be small. When $T_{\text {coherence }}$ changes from 0.14 or 0.16 to 0.18 , the percentage of agreement increases in the snow accumulation period but decreases in the snowmelt period. The trend of changes is in the opposite direction. Thus, the use of $T_{\text {coherence }}=0.16$ should be not only empirical but also reasonable.

Table 7. Spatial agreement of snow maps using $T_{\text {coherence }}$ of 0.14 and 0.18 with those using Landsat 5 TM data in snow accumulation and snowmelt periods.

\begin{tabular}{ccc}
\hline $\mathbf{T}_{\text {coherence }}$ & In Snow Accumulation Period & In Snowmelt Period \\
\hline 0.14 & $61.9 \%$ & $80.1 \%$ \\
0.18 & $74.4 \%$ & $77.8 \%$ \\
\hline
\end{tabular}




\section{Conclusions}

The snow on the alpine ground can be dry or wet, or even be completely melted. Thus, snow status in alpine areas is a function of time. When two SAR data are paired to form InSAR coherence data, the coherence values should reveal the snow status changes occurring between two data acquisitions. Intuitively, there is a potential relationship between the coherence value and thawing and freezing changes of snow. Therefore, we evaluate the ability to use the repeat-pass PALSAR HH coherence data to detect the status change of snow above the tree line, and map the change using multitemporal coherence data on Mt. Dagu, Sichuan, China.

With the ancillary MODIS land surface temperature and GDEM datasets, we not only identified the snow status above the tree line when three SAR data were acquired, but also inferred that the coherence pair of 22 February 2008 (master) and 8 April 2008 (slave) was within the snow accumulation period. The coherence pair of 8 April 2008 (master) and 24 May 2008 (slave) was in the snowmelt period. After decomposing the coherence data, we developed an algorithm to delineate the change of snow statuses between 22 February and 8 April, from 8 April to 24 May, and between 22 February and 24 May.

From February to April, the area with increase of snow was $348.9 \mathrm{~km}^{2}$ and the area without change was $183.1 \mathrm{~km}^{2}$. The snow was accumulating. Since the ground surface temperature of the master image or slave image at acquisition time was both below $0{ }^{\circ} \mathrm{C}$, the snow status was Dry-Dry. Between April and May, the land surface temperature at the acquisition time for the master image was $-12{ }^{\circ} \mathrm{C}$, but was $2{ }^{\circ} \mathrm{C}$ when the slave image was acquired. The snow status should be Dry-Wet in the permanent snow covered area, and Dry-Wet or Dry-No in the grazing zone. The area showing the decrease of snow was $224.1 \mathrm{~km}^{2}$. The area without change was $307.9 \mathrm{~km}^{2}$. Thus, the snow was melting. Finally, within the entire period (February to May), the area with snow accumulation and Dry-Dry status was $348.9 \mathrm{~km}^{2}$, but the area with decrease of snow and Dry-Wet was $224.1 \mathrm{~km}^{2}$. Therefore, there should be $124.8 \mathrm{~km}^{2}$ of area where the snow was melted completed or the snow status was Dry-No.

To evaluate the results, we used three nearly concurrent Landsat 5 TM images to derive areas with snow increase or no snow change in the accumulation period, and areas with snow decrease or no snow change in the snowmelt period. In comparison of the results derived from the InSAR and TM data, the spatial agreement was $71.3 \%$ for the accumulation period, and $79.5 \%$ for the snowmelt period. The percentages could be acceptable to warrant a satisfactory evaluation.

\section{Acknowledgments}

This study was supported by the National Natural Science Foundation of China under grant 41471361 to the University of Electronic Science and Technology of China, UESTC, and the Fundamental Research for the Central Universities of China under grant ZYGX2013Z006 to the UESTC. PALSAR data $\left({ }^{\odot} \mathrm{JAXA}\right.$, Ministry of Economy, Trade, and Industry of Japan) were obtained from the Alaska Satellite Facility (ASF). Special thanks are given to the personnel of the User Support Office, ASF, who processed numerous PALSAR images. 


\section{Author Contributions}

Yong Wang, Lei Wang, Hong Li, Yuanyuan Yang, and Taoli Yang initiated the research. Under the supervision of Yong Wang, Lei Wang performed the analysis. Yong Wang, Lei Wang, Hong Li, Yuanyuan Yang, and Taoli Yang wrote and revised the manuscript. All authors read and approved the final version of the manuscript.

\section{Conflicts of Interest}

The authors declare no conflict of interest.

\section{References}

1. Barnett, T.P.; Adam, J.C.; Lettenmaier, D.P. Potential impacts of a warming climate on water availability in snow-dominated regions. Nature 2005, 438, 303-309.

2. Baghdadi, N.; Gauthier, Y.; Bernier, M. Capability of multitemporal ERS-1 SAR data for wet-snow mapping. Remote Sens. Environ. 1997, 60, 174-186.

3. Nagler, T.; Rott, H. Retrieval of wet snow by means of multitemporal SAR data. IEEE Trans. Geosci. Remote Sens. 2000, 38, 754-765.

4. Longepe, N.; Shimada, M.; Allain, S.; Pottier, E. Capabilities of full-polarimetric PALSAR/ALOS for snow extent mapping. In Proceedings of the 2008 IEEE International Geoscience and Remote Sensing Symposium, Boston, MA, USA, 7-11 July 2008; Volume 4, pp. 1026-1029.

5. Park, S.E.; Yamaguchi, Y.; Singh, G.; Yamaguchi, S.; Whitaker, A.C. Polarimetric SAR response of snow-covered area observed by multi-temporal ALOS PALSAR fully polarimetric mode. IEEE Trans. Geosci. Remote Sens. 2014, 52, 329-340.

6. Singh, G.; Venkataraman, G.; Yamaguchi, Y.; Park, S.E. Capability assessment of fully Polarimetric ALOS-PALSAR data for discriminating wet snow from other scattering types in mountainous regions. IEEE Trans. Geosci. Remote Sens. 2014, 52, 1177-1196.

7. Guneriussen, T.; Hogda, K.A.; Johnsen, H.; Lauknes, I. InSAR for estimation of changes in snow water equivalent of dry snow. IEEE Trans. Geosci. Remote Sens. 2001, 39, 2101-2108.

8. Oveisgharan, S.; Zebker, H.A. Estimating snow accumulation from InSAR correlation observations. IEEE Trans. Geosci. Remote Sens. 2007, 45, 10-20.

9. Li, Z.; Guo, H.; Li, X.; Wang, C. SAR interferometry coherence analysis for snow mapping. In Proceedings of the 2001 IEEE International Geoscience and Remote Sensing Symposium, Sydney, Australia, 9-13 July 2001; pp. 2905-2907.

10. Singh, G.; Venkataraman, G.; Rao, Y.S.; Kumar, V.; Mani, S. InSAR coherence measurement techniques for snow cover mapping in Himalayan region. In Proceedings of the 2008 IEEE International Geoscience and Remote Sensing Symposium, Boston, MA, USA, 7-11 July 2008.

11. Kumar, V.; Venkataraman, G. SAR interferometric coherence analysis for snow cover mapping in the western Himalayan region. Int. J. Digit. Earth 2010, 4, 78-90.

12. About ALOS-PALSAR. Available online: http://www.eorc.jaxa.jp/ALOS/en/about/palsar.htm (accessed on 31 August 2015).

13. Alaska Satellite Facility. Available oneline: https://www.asf.alaska.edu (accessed on 31 August 2015). 
14. Li, J.L.; Bao, A.M.; Huang, Q.T. A object-oriented glacier mapping method based on multi-temporal Landsat images. In Proceedings of the MIPPR 2013: Remote Sensing Image Processing, Geographic Information Systems, and Other Applications, Wuhan, China, 26 October 2013.

15. Wang, T.; Liao, M.S.; Perissin, D. InSAR coherence-decomposition analysis. IEEE Trans. Geosci. Remote Sens. Letters. 2010, 7, 156-160.

16. Gatelli, F.; Monti Guamieri, A.; Parizzi, F.; Pasquali, P.; Prati, C.; Rocca, F. The wavenumber shift in SAR interferometry. IEEE Trans. Geosci. Remote Sens. 1994, 32, 855-865.

17. Zebker, H.A.; Villasenor, J. Decorrelation in interferometric radar echoes. IEEE Trans. Geosci. Remote Sens. 1992, 30, 950-959.

18. Krieger, G.; Moreira, A.; Fiedler, H.; Hajnsek, I.; Werner, M.; Younis, M.; Zink, M. TanDEM-X: A satellite formation for high-resolution SAR interferometry. IEEE Trans. Geosci. Remote Sens. 2007, 45, 3317-3341.

19. Rott, H.; Siegel, A. Glaciological studies in the Alps and in Antarctica using ERS interferometric SAR. In Proceedings of the Fringe 96' Workshop on ERS SAR Interferometry, Zürich, Switzerland, 30 September-2 October 1996; pp. 149-159.

20. Wang, Y.; Wang, L.; Zhang, Y.; Yang, T. Investigation of snow cover change using multi-temporal PALSAR InSAR data at Dagu Glacier, China. In Proceedings of the 2015 IEEE International Geoscience and Remote Sensing Symposium, Milan, Italy, 26-31 July 2015; pp. 747-750.

21. Klein, A.G; Hall, D.K; Riggs, G.A. Improving snow cover mapping in forests through the use of a canopy reflectance model. Hydrol. Process. 1998, 12, 1723-1744.

(C) 2015 by the authors; licensee MDPI, Basel, Switzerland. This article is an open access article distributed under the terms and conditions of the Creative Commons Attribution license (http://creativecommons.org/licenses/by/4.0/). 